\title{
Development of Integrated Curricula for the Master of Engineering Programs Using the CDIO Framework
}

\author{
https://doi.org/10.3991/ijep.v9i3.10112 \\ Harold Jan R. Terano \\ Camarines Sur Polytechnic Colleges, Camarines Sur, Philippines \\ haroldterano@cspc.edu.ph
}

\begin{abstract}
This research presents the revision of the current curriculum of the Master of Engineering program at Camarines Sur Polytechnic Colleges in the Philippines through series of consultations and focus group discussions with the faculty and students of the graduate program and industry practitioners, and the development of integrated curricula using the CDIO framework. Standards $1,2,3,4$ and 5 and syllabus v2.0 of the CDIO framework were used in the development of the integrated curricula. Graduate attributes were developed, and the result of the industry needs survey served as one of the bases in the integration of various skill sets in the integrated curricula for the master of engineering programs.
\end{abstract}

Keywords-CDIO, CDIO framework, CDIO standards, CDIO syllabus, curriculum, integrated curriculum, Master of Engineering

\section{$1 \quad$ Introduction}

The outcomes of the student learning can be determined by how well an educational institution design and to implement the entire curriculum for a specific program. The development of curriculum for educational programs can be influenced by a number of sources. The goals of the program could be defined based on the funding source, the community, government departments of education (state and federal level), or by the educator who is designing the activity [1].

$\mathrm{CDIO}$ is an international initiative in reforming education. CDIO framework has been the current trend, and it influences the reformation of engineering education. It is an innovative educational framework for producing the next generation of engineers. The framework provides students with an education stressing engineering fundamental set in the context of Conceiving-Designing Designing - Implementing - Operating (CDIO) real-world systems and products [2]. The current educational setup must be aligned to the current needs of the industry and skills gap is a common problem between university products and industry needs [3]. To cope in this competitive world, a well-designed curriculum must be designed to satisfy with the international standards of engineering education that focus on the attainment of the needs of the industry.

In the Philippines, CDIO was first to introduced with the partnership of Singapore Polytechnic and Temasek Foundation. One of the nine State Universities and Colleges 
in the Philippines is the Camarines Sur Polytechnic Colleges that undergone series of trainings and seminars both in the Philippines and Singapore on the CDIO Framework. Six faculty members of the College of Engineering were trained to become Master Trainers that has the role of cascading CDIO not just in the college but to all Colleges and Universities in the Philippines.

Camarines Sur Polytechnic Colleges popularly known as CSPC is a state college in the Philippines. It is mandated primarily to provide higher technological, professional and vocational instruction and training in fisheries, trade and technology, arts and sciences, as well as short term technical and vocational courses, as the Board of Trustees may deem necessary, and shall promote researches in the exploration and conservation of natural resources in the province [4]. The vision of the college is to be the regional center of excellence in polytechnic education. Presently, CSPC has two campuses: the main campus in Nabua, Camarines Sur and Buhi Extension campus. In the main campus, the institution has 5 colleges, namely, College of Engineering, College of Health Care Technology, College of Management and Entrepreneurship, College of Information and Communications Technology, and College of Education, Arts and Sciences. The college offers 2 levels of educational programs in various disciplines: bachelor's degree and master's degree programs.

CSPC has been one of the leading engineering institutions in the Bicol Region. The College of Engineering puts its goals in providing quality instruction and training in engineering through the ladderized curricula in civil, electrical, mechanical and electronics engineering which are responsive and relevant to the needs and development of the service area in particular and the country in general as well as develop total quality engineers and technology researchers for industry and society to maximally contribute to sustainable national development [5].

The first master's program offered by the college in the last 20 years was the Master of Arts in Teaching Engineering Technology (MATET) and then it was changed to Master of Arts in Engineering Technology (MAET) and Master in Engineering Technology (MET). Currently, the name of the program was change in 2014 to Master of Engineering (M.Eng'g). The program offers specializations in Civil Engineering, Mechanical Engineering, Electrical Engineering and Electronics Engineering. Based on the tracer study of Barandon conducted in 2016, the graduates of the program at CSPC from 2004 to 2015 is fifty-five (55). From 2016 to present, the enrollees of the program greatly increased and in 2018, the current number of students is eighty (80).

CSPC is one of the two higher education institutions in Bicol region to offer a master's program in engineering catering engineering professionals and practitioners in the six (6) provinces of Bicol. The main objective of the study is to develop integrated curricula for the master of engineering programs using the CDIO framework guided by the current educational standards and requirements of the graduate program in engineering, and the results of industry needs survey. 


\section{$2 \quad$ Literature Review}

The following are reviews on CDIO that served as the basis in the development of the integrated curricula for the master of engineering programs.

\subsection{CDIO and the Educational Standards and Accreditation}

The adoption of the CDIO Initiative at the School of Engineering, Nanyang Polytechnic, Singapore contributed to the ABET accreditation of the Diploma in Aerospace and Aeronautical Engineering. The CDIO played a key role in meeting the ABET criteria; the success of the accreditation within a short span of time is shaped by the strategic foundation for NY organizational excellence - Culture, Concept, Capability and Connection/Collaboration [6].

CDIO standards are accepted to be compliant with the Washington accord. With the CDIO process, the CDIO Standards and the CDIO Syllabus, many scholarly contributions have been made around cultural change, curriculum reform and learning environments. The CDIO Syllabus cast into the Australian context by mapping it to the Engineers Australia Graduate Attributes, the Washington Accord Graduate Attributes and the Queensland University of Technology Graduate Capabilities [7].

The Tomsk Polytechnic University carried out the analysis of the existing Academic Standard to understand whether it requires some changes and to identify the possibilities of its improvement. The analysis was aimed at the development of a basis for a new edition of the TPU Standard in the frame of CDIO context [8].

With these literatures, it is to note that CDIO is a worldwide accepted framework for engineering education. It conforms to various educational standards such as the Washington Accord and incorporates outcomes-based education. It is compliant to the standards of engineering education and accreditations of programs

\subsection{CDIO standards}

The CDIO framework is consists of 12 CDIO Standards [9]. Standard 1 focused on program philosophy. Standards 2, 3 and 4 is on the curriculum development. Standards 5 and 6 are on design-build experiences and workspaces. Standards 7 and 8 are on new methods of teaching and learning. Standards 9 and 10 is on faculty development. And standards 11 and 12 is on assessment and evaluation.

\subsection{CDIO syllabus}

The syllabus is the cornerstone of CDIO. It offers rational, complete, universal and generalizable goals for undergraduate engineering education [10]. The CDIO syllabus was developed through discussions with focus groups comprised of various stakeholders, and by reference to other documentation of the time [11]. The CDIO syllabus is composed of learning outcomes that are classified into four high-level categories, namely, technical knowledge, personal and professional attributes, interpersonal 
skills, and the skills specific to the engineering profession. Table 1 shows the CDIO Syllabus v2.0 [12].

Table 1. CDIO Skill Sets

\begin{tabular}{|l|}
\multicolumn{1}{|c|}{ CDIO Syllabus v2.0 } \\
\hline 1. Disciplinary Knowledge and Reasoning \\
1.1 Knowledge of Underlying Mathematics and Science \\
1.2 Core Engineering Fundamental Knowledge \\
1.3 Advanced Engineering Fundamental Knowledge, Methods and Tools \\
\hline 2. Personal and Professional Skills and Attributes \\
2.1 Analytical Reasoning and Problem Solving \\
2.2 Experimentation, Investigation and Knowledge Discovery \\
2.3 System Thinking \\
2.4 Attitudes, Thought and Learning \\
2.5 Ethics, Equity and other Responsibilities \\
\hline 3. Interpersonal Skills: Teamwork and Communication \\
3.1 Multidisciplinary Teamwork \\
3.2 Communications \\
3.3 Communications in Foreign Languages \\
\hline 4. Conceiving, Designing, Implementing, and Operating Systems in the Enterprise and Societal \\
Contexts \\
4.1 External, Societal and Environmental Context \\
4.2 Enterprise and Business Context \\
4.3 Conceiving, Systems Engineering and Management \\
4.4 Designing \\
4.5 Implementing \\
4.6 Operating
\end{tabular}

\section{Methodology}

This study was focused on the development of integrated curricula for the master of engineering programs using the CDIO framework. The Master of Engineering Programs at Camarines Sur Polytechnic Colleges, a higher education institution in the Philippines was the subject of the study. Revisions of the curricula were done through a series of consultations and FGDs with the faculty and students of the graduate program, and industry practitioners in order to obtain the most important courses and descriptions to be developed. Review of the CDIO standards and syllabus formed part in the whole processes of the development of the integrated curricula. Graduate attributes were developed, and industry needs survey on the expected proficiency of graduate students were gathered that served as inputs in the integration of the CDIO skill sets in the developed curricula. The questionnaire survey was obtained using the CDIO Syllabus v2.0. Respondents were asked to assess the expected level of proficiency, using a set of descriptors as shown in Table 2, in the range of skill sets of the CDIO syllabus [13]. 
Table 2. Expected Level of Proficiency Descriptors

\begin{tabular}{|l|l|}
\hline 1 & To have experienced or been exposed to \\
\hline 2 & To be able to participate in and contribute to \\
\hline 3 & To be able to understand and explain \\
\hline 4 & To be skilled in the practice or implementation \\
\hline 5 & To be able to lead or innovate in \\
\hline
\end{tabular}

The participants of the study were classified into two groups. The first group is the composition of the faculty and students of the graduate program, and industry practitioners. They served as the informants to the series of consultations and FGDs in the revision of the curricula which include the course contents and descriptions. The second group of respondents is the primary engineering industries in the Bicol region, Philippines where the majority of graduate students are employed. They served as the respondents of the industry needs survey in determining the expected levels of proficiency of graduate students. Arithmetic mean and standard deviation were the statistical tools used in the analysis of data. Cronbach's Alpha was used to determine the reliability of the survey. Microsoft Excel was used in the analysis of the data.

\section{$4 \quad$ Results and Discussions}

\subsection{Graduate Attributes}

On the curriculum development process, five CDIO standards were involved. These are standards 1, 2, 3, 4 and 5 [14]. To meet standard 1, it is understood to indicate that the curriculum has adopted CDIO as a context for the master of engineering education. To meet standard 2, graduate attributes are necessary. Graduate attributes are essential factors in planning the curriculum of any university. The five themes generated represent the main areas of engineering attributes regulated by national bodies [15]. These are knowledge base, professionalism, problem solving, diverse work settings and design. These attributes were derived from the data of countries under the Washington Accord. Currently, the college doesn't have clear statements on the graduate attributes. The proposed attributes were developed and meet the global graduate attribute themes and categories as shown in Table 3.

The graduate attributes conformed to the CDIO knowledge and skill sets from CDIO syllabus as shown in Table 4. 
Table 3. Proposed CSPC Graduate Attributes

\begin{tabular}{|c|l|l|l|}
\hline No. & Global Themes & \multicolumn{2}{|c|}{ Proposed Graduate Attributes } \\
\hline 1 & Knowledge Base & Deep Discipline Knowledge & $\begin{array}{l}\text { Graduates who have the knowledge and mastery } \\
\text { of the fundamental and advanced concepts re- } \\
\text { quired for effective practice of their respective } \\
\text { fields of disciplines. }\end{array}$ \\
\hline 2 & $\begin{array}{l}\text { Professionalism } \\
\text { Problem Solving } \\
\text { Design }\end{array}$ & $\begin{array}{l}\text { Professional Skills and } \\
\text { Competence }\end{array}$ & $\begin{array}{l}\text { Graduates who have basic and advanced practice } \\
\text { in their fields, able to think, design, build and } \\
\text { solve problems to respond to the needs of the } \\
\text { industry and community. }\end{array}$ \\
\hline 3 & $\begin{array}{l}\text { Diverse Work } \\
\text { Settings }\end{array}$ & $\begin{array}{l}\text { Personal and Interpersonal } \\
\text { Skills }\end{array}$ & $\begin{array}{l}\text { Graduates apply effective communication skills } \\
\text { both orally and in writing, give importance to } \\
\text { life-long learning, and work effectively in multi- } \\
\text { disciplinary and multicultural teams. }\end{array}$ \\
\hline 4 & $\begin{array}{l}\text { Diverse Work } \\
\text { Settings }\end{array}$ & $\begin{array}{l}\text { Socially Responsible and } \\
\text { Ethical }\end{array}$ & $\begin{array}{l}\text { Graduates give importance to moral values and } \\
\text { beliefs, and understand social and ethical respon- } \\
\text { sibilities. }\end{array}$ \\
\hline 5 & Design & Productivity & $\begin{array}{l}\text { Graduates contribute to nation-building and } \\
\text { development, and industrial innovation through } \\
\text { creative generation of technologies. }\end{array}$ \\
\hline
\end{tabular}

Table 4. CDIO Skillsets-Future Graduate Attributes Mapping

\begin{tabular}{|c|c|c|c|c|c|}
\hline \multirow{2}{*}{ CDIO Skill Sets based on CDIO Syllabus v.20 } & \multicolumn{5}{|c|}{ Desired Graduate Attributes } \\
\hline & 1 & 2 & 3 & 4 & 5 \\
\hline \multicolumn{6}{|l|}{ 1. Disciplinary Knowledge and Reasoning } \\
\hline \multicolumn{6}{|l|}{1.1 Knowledge of Underlying Mathematics and Science } \\
\hline \multicolumn{6}{|l|}{ 1.2 Core Engineering Fundamental Knowledge } \\
\hline \multicolumn{6}{|l|}{$\begin{array}{l}\text { 1.3 Advanced Eng'g. Fundamental Knowledge, Methods \& } \\
\text { Tools }\end{array}$} \\
\hline \multicolumn{6}{|l|}{ 2. Personal and Professional Skills and Attributes } \\
\hline \multicolumn{6}{|l|}{ 2.1 Analytical Reasoning and Problem Solving } \\
\hline \multicolumn{6}{|l|}{$\begin{array}{l}\text { 2.2 Experimentation, Investigation and Knowledge Discov- } \\
\text { ery }\end{array}$} \\
\hline \multicolumn{6}{|l|}{2.3 System Thinking } \\
\hline \multicolumn{6}{|l|}{ 2.4 Attitudes, Thought and Learning } \\
\hline \multicolumn{6}{|l|}{2.5 Ethics, Equity and other Responsibilities } \\
\hline \multicolumn{6}{|l|}{ 3. Interpersonal Skills: Teamwork and Communication } \\
\hline \multicolumn{6}{|l|}{ 3.1 Multidisciplinary Teamwork } \\
\hline \multicolumn{6}{|l|}{ 3.2 Communications } \\
\hline \multicolumn{6}{|l|}{ 3.3 Communications in Foreign Languages } \\
\hline \multicolumn{6}{|l|}{$\begin{array}{l}\text { 4. Conceiving, Designing, Implementing, and Operating } \\
\text { Systems in the Enterprise and Societal Contexts }\end{array}$} \\
\hline \multicolumn{6}{|l|}{ 4.1 External, Societal and Environmental Context } \\
\hline \multicolumn{6}{|l|}{4.2 Enterprise and Business Context } \\
\hline \multicolumn{6}{|l|}{ 4.3 Conceiving, Systems Engineering and Management } \\
\hline \multicolumn{6}{|l|}{4.4 Designing } \\
\hline \multicolumn{6}{|l|}{4.5 Implementing } \\
\hline 4.6 Operating & & & & & \\
\hline
\end{tabular}




\subsection{Industry Needs Survey Results}

Twenty (20) questionnaires were returned. The computed Cronbach's Alpha was 0.855 which is higher than 0.700 , thus, the survey was reliable. Table 5 shows the result of the survey of the proficiency expectation from the industry. It is found that multidisciplinary teamwork, advanced engineering fundamental knowledge, methods and tools, attitudes, thought and learning, ethics, equity and other responsibilities, and communications were the top expectations. The lowest expectations are communications in foreign languages and enterprise and business context. Results show similarities of the findings of Kuptasthien [16] in 2014. Also, in the results of the study of Ercan, et al., [17], they observed that engineering as well as communication and teamwork skills of students participated in their program developed significantly, which proves that these skills must be integrated in the curriculum.

Table 5. Result of Industry Needs Survey

\begin{tabular}{|c|l|c|c|}
\hline No. & \multicolumn{1}{|c|}{ Skill Sets } & Mean & Std. Dev. \\
\hline 3.1 & Multidisciplinary Teamwork & 4.500 & 0.671 \\
\hline 1.3 & Advanced Eng'g. Fundamental Knowledge, Methods and Tools & 4.250 & 0.829 \\
\hline 2.4 & Attitudes, Thought and Learning & 4.250 & 0.622 \\
\hline 2.5 & Ethics, Equity and other Responsibilities & 4.200 & 0.600 \\
\hline 3.2 & Communications & 4.200 & 0.600 \\
\hline 1.2 & Core Engineering Fundamental Knowledge & 4.150 & 0.572 \\
\hline 4.4 & Designing & 4.150 & 0.654 \\
\hline 2.1 & Analytical Reasoning and Problem Solving & 4.050 & 0.669 \\
\hline 2.3 & System Thinking & 4.050 & 0.497 \\
\hline 4.3 & Conceiving, Systems Engineering and Management & 4.000 & 0.548 \\
\hline 1.1 & Knowledge of Underlying Mathematics and Science & 3.950 & 0.589 \\
\hline 4.5 & Implementing & 3.850 & 0.853 \\
\hline 2.2 & Experimentation, Investigation and Knowledge Discovery & 3.750 & 0.698 \\
\hline 4.1 & External, Societal and Environmental Context & 3.700 & 0.900 \\
\hline 4.6 & Operating & 3.700 & 0.843 \\
\hline 3.3 & Communications in Foreign Languages & 3.550 & 0.669 \\
\hline 4.2 & Enterprise and Business Context & 3.500 & 0.806 \\
\hline
\end{tabular}

\subsection{Revisions of the curriculum}

The revision of the curriculum was done through a series of consultations and FGDs with the faculty and students of the graduate program, and industry practitioners. The contents of the curriculum were based on the needs of the industry and the capability of the faculty members to handle specialized courses. The faculty suggested that the major courses should only focus on one specialization in each program since the previous curriculum focuses on various specializations. In this revision, four major courses were designed in each program as shown in Table 6. 
Table 6. Proposed Curriculum: Master of Engineering in Civil Engineering

\begin{tabular}{|c|c|c|c|}
\hline \multicolumn{4}{|c|}{ Foundation Courses (12 units) } \\
\hline $\begin{array}{l}\text { Course } \\
\text { Code }\end{array}$ & $\begin{array}{l}\text { Pre-Requisite } \\
\text { /Co-Requisite }\end{array}$ & Course Title & Units \\
\hline ET 200 & None & Engineering Research and Development & 3 \\
\hline ET 201 & None & $\begin{array}{l}\text { Probability and Statistical Concepts in Engineering Plan- } \\
\text { ning and Design }\end{array}$ & 3 \\
\hline ET 202 & None & Computer Engineering & 3 \\
\hline ET 203 & None & Advanced Engineering Mathematics I & 3 \\
\hline \multicolumn{4}{|c|}{ Core Courses (15 units) } \\
\hline ET 204 & ET 203 & Advanced Engineering Mathematics II & 3 \\
\hline ET 205 & /ET 203 /ET 202 & Numerical Methods with Computer Applications & 3 \\
\hline ET 206 & None & Production Engineering and Management & 3 \\
\hline ET 207 & ET 202 & Computer-Aided Design Applications & 3 \\
\hline ET 208 & None & Environment, Energy \& Technology Management & 3 \\
\hline \multicolumn{4}{|c|}{ M.Eng'g. in Civil Engineering: Structural Engineering (12 units) } \\
\hline CE 200 & ET 204, ET 205 & Advanced Structural Analysis & 3 \\
\hline CE 201 & ET 204, ET 205 & Advanced Reinforced Concrete Design & 3 \\
\hline CE 202 & ET 204, ET 205 & Prestressed Concrete Design & 3 \\
\hline CE 203 & ET 204, ET 205 & Structural Dynamics and Earthquake Engineering & 3 \\
\hline \multicolumn{4}{|c|}{$\begin{array}{l}\text { M.Eng'g. in Mechanical Engineering: Heat Transfer, Thermodynamics and Energy Systems } \\
\text { (12 units) }\end{array}$} \\
\hline ME 200 & ET 204, ET 205 & Combustion Engineering & 3 \\
\hline ME 201 & ET 204, ET 205 & Thermal Engineering & 3 \\
\hline ME 202 & ET 204, ET 205 & Two-Phase Flow and Heat Transfer & 3 \\
\hline ME 203 & ET 204, ET 205 & Thermal Science Application in Power Engineering & 3 \\
\hline \multicolumn{4}{|c|}{ M.Eng'g. in Electrical Engineering Major Courses: Power Engineering (12 units) } \\
\hline EE 200 & ET 204, ET 205 & Power System Operation \& Controls & 3 \\
\hline EE 201 & ET 204, ET 205 & Power Transmission and Distribution & 3 \\
\hline EE 202 & ET 204, ET 205 & Computer Applications in Power Systems & 3 \\
\hline EE 204 & ET 204, ET 205 & Renewable Energy Resources Design & 3 \\
\hline \multicolumn{4}{|c|}{ M.Eng'g. in Electronics Engineering: Robotics and Control Engineering (12 units) } \\
\hline ECE200 & ET 204, ET 205 & Electronic Systems and Instrumentation & 3 \\
\hline ECE201 & ET 204, ET 205 & Robotics and Mechatronics Engineering & 3 \\
\hline ECE202 & ET 204, ET 205 & Modern Control Systems & 3 \\
\hline ECE203 & ET 204, ET 205 & Digital Control Systems & 3 \\
\hline \multirow[t]{2}{*}{ ET 210} & & 140 HOURS Industry Immersion & 3 \\
\hline & & Comprehensive Exam & \\
\hline \multirow[t]{2}{*}{ ET 211} & & Thesis Writing & 6 \\
\hline & & Total Units & 48 \\
\hline
\end{tabular}




\subsection{Integrated curricula using the CDIO framework}

From the results of the survey, the top five industry expectations are multidisciplinary teamwork, advanced engineering fundamental knowledge, methods and tools, attitudes, thought and learning, ethics, equity and other responsibilities, and communications. Multidisciplinary teamwork, attitudes, thought and learning, and communications were integrated into the developed curricula. Communications will be taught (T) in the course engineering research and development.

While the multidisciplinary teamwork, and attitudes, thought and learning will be used (U) and be assessed (A) in the various courses of the program as shown in the integrated curriculum. Course syllabi on these courses should be designed and incorporated the various skill-sets as presented in the curriculum.

The foundation courses serve as the fundamentals of engineering as stated in standard 4. Four major courses were incorporated in the curriculum to enhance the implementing skills along with Design \& Build experience (standard 5). Figures 1 to 3 shows the gap analysis, skill map and full integrated curriculum.

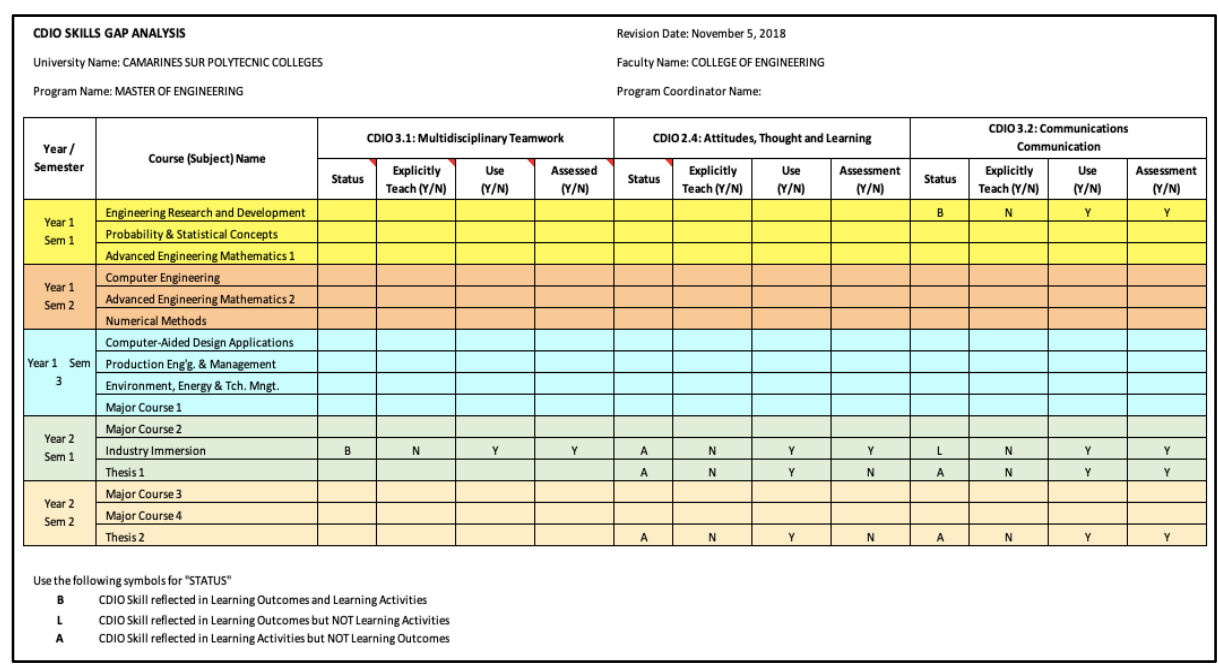

Fig. 1. Current Gap Analysis 


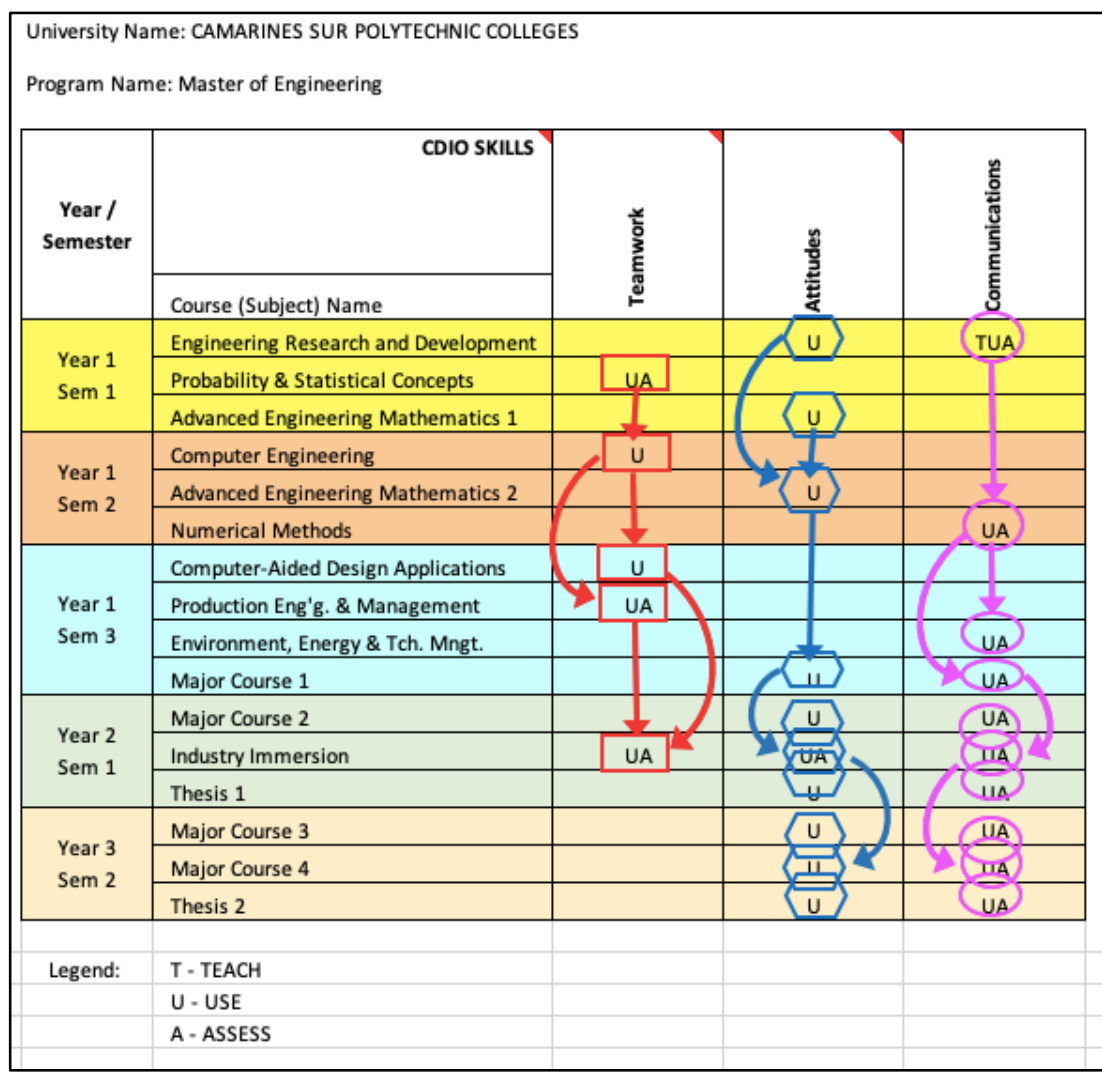

Fig. 2. Skill Map

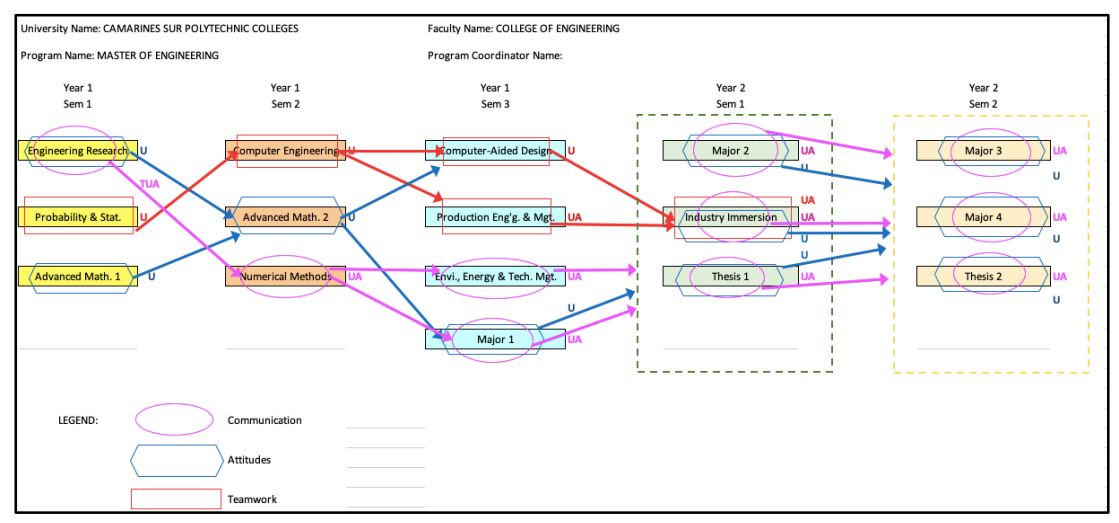

Fig. 3. Integrated Curriculum (Same for the Four Programs) 


\section{Conclusion and Recommendations}

The developed integrated curricula for the master of engineering programs using CDIO framework conforms with the current educational standards in engineering education. The contents of the curricula were revised. Graduate attributes were developed, and the industry needs survey was conducted as bases in the integration of various skill-sets and attributes of graduate students. Multidisciplinary teamwork, attitudes, thought and learning, and communications were integrated into the curricula. Policies regarding admission, industry immersion, comprehensive examination, thesis/research, and other academic-related policies on the master's degree in engineering which are not part of this study can be developed based on the approaches of the CDIO framework. The developed curricula can now be in the process for approval with the academic council for implementation. Stakeholder's validation will be essential to determine the effectiveness of the developed curricula. Faculty professional and teaching enhancement will lead to a successful implementation of the developed curricula.

\section{Acknowledgement}

The author would like to acknowledge the participation of the professors and students of the Graduate School, Camarines Sur Polytechnic Colleges, Philippines, and industry practitioners. Also, he would like to extend warmest thanks to the Camarines Sur Polytechnic Colleges, Philippines for the approval and funding of this study.

\section{$7 \quad$ References}

[1] Campbel, B.R., Voelker, J.J., and Kremer, C.S. (2015). An analysis of engineering educational standards and outcomes achieved by a robotics summer camp experience. International Journal of Engineering Pedagogy, 5(4), 12-21. Retrieved from www.onlinejournals.org. Accessed on November 6, 2018. https://doi.org/10.3991/ijep.v5i4.4713

[2] About CDIO. (n.d.). Retrieved from http://www.cdio.org/about. Accessed on August 7, 2018.

[3] Mammi, H.K. and Ithnim, N. (2012). Competency based education (CBE) for IT security: towards bridging the gap. International Journal of Engineering Pedagogy, 2(4), 24-26. Retrieved from www.online-journals.org. Accessed on October 4, 2018.

[4] Philippine Batas Pambansa 512 Section 2.

[5] Camarines Sur Polyetchnic Colleges (CSPC), Available: http://cspc.edu.ph/aca demics/college-of-engineering/ Accessed on September 10, 2018.

[6] Wah, C.K, Tan, D. and Wee K. S. (2015, June 8-11). CDIO and ABET accreditation-the Nanyang Polytechnic Experience. Paper presented at the 11th International CDIO Conference, Chengdu University of Information Technology, Chengdu, Sichuan, P.R. China.

[7] Campbell, D., Dawes, L., Beck, H., Wallace, S., and Boman, M. (2009, December 6-9). Graduate attribute mapping with the extended CDIO framework. Paper presented at the $20^{\text {th }}$ Australasian Association for Engineering Education Conference 2009. 
[8] Chuchalin A. I., Petrovskaya, T. S., Kulyukina, E. S., and Tayurskaya, M. S. (2012, July 14). Benchmarking of TPU academic standards and CDIO standards in engineering education. Paper presented at the 8th International CDIO Conference, Queensland University of Technology, Brisbane.

[9] CDIO Standards 2.0. (n.d.). Retrieved from http://www.cdio.org/implementingcdio/standards/12-cdio-standards https://doi.org/10.12737/5875

[10] CDIO Syllabus. (n.d.), Retrieved from http://www.cdio.org/framework-benefits/cdiosyllabus https://doi.org/10.21125/iceri.2016.0393

[11] F Crawley, Edward \& Malmqvist, Johan \& Lucas, William \& R Brodeur, Doris. (2011, June 20-23). The CDIO syllabus v2.0: an updated statement of goals for engineering education. Paper presented at the $7^{\text {th }}$ International CDIO Conference, Technical University of Denmark, Copenhagen.

[12] F Crawley, Edward \& Malmqvist, Johan \& Lucas, William \& R Brodeur, Doris. (2011, June 20-23). The CDIO syllabus v2.0: an updated statement of goals for engineering education. Paper presented at the $7^{\text {th }}$ International CDIO Conference, Technical University of Denmark, Copenhagen.

[13] Crawley, E.F. (2001). The CDIO syllabus: a statement of goals for undergraduate engineering education. Available: http://www.cdio.org/files/CDIO Syllabus Report.pdf $\backslash$ Accessed on September 22, 2018. https://doi.org/10.1109/fie.2002.1158202

[14] Kuptasthien, N., Triwanapong, S., and Kanchana, R. (2016). Integrated curriculum development in industrial engineering program using CDIO framework. Communications, 3, 30-37. Retrieved from http://aeer.ru/filesen/io/m16/art 3.pdf. Accessed on October 10, 2018.

[15] Paul, R., Hugo, R. J. and Falls, L. C. (2015, June 8-11). International expectations of engineering graduate attributes. Paper presented at the 11th International CDIO Conference, Chengdu University of Information Technology, Chengdu, Sichuan, P. R. China.

[16] Kuptasthien, N., Triwanapong, S., and Kanchana, R. (2016). Integrated curriculum development in industrial engineering program using CDIO framework. Communications, 3, 30-37. Retrieved from http://aeer.ru/filesen/io/m16/art 3.pdf. Accessed on July 18, 2018.

[17] Ercan, M.F., Sale, D. and Kristian, N. (2016). Innovative curriculum to enhance the learning experience of electrical and mechanical engineering students. International Journal of Engineering Pedagogy, 6(3), 37-44. Retrieved from www.online-journals.org. Accessed on November 21, 2018. https://doi.org/10.3991/ijep.v6i3.5765

\section{Author}

Harold Jan R. Terano is a registered electronics engineer and a licensed professional teacher in Mathematics. He obtained degrees in Bachelor of Science in Electronics and Communication Engineering and Master in Engineering Technology. He finished academic requirements for $\mathrm{PhD}$ in Mathematics Education at the Bicol University Graduate School, Philippines. He published various books and researches in international circulation. Currently, he is a faculty member of the College of Engineering and Graduate School at Camarines Sur Polytechnic Colleges, Philippines.

Article submitted 2019-01-06. Resubmitted 2019-02-11. Final acceptance 2019-02-11. Final version published as submitted by the authors. 